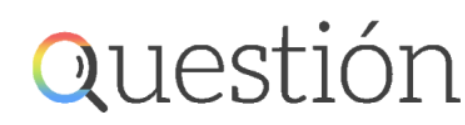

Periodismo / Comunicación ISSN 1669-6581
- Av. $44 \mathrm{~N}^{\circ} 676,1^{\circ}$ piso

CP 1900 - La Plata - Argentina

www.perio.unlp.edu.ar/question

Ensayo general de mis sentimientos

Florencia Cremona

https://doi.org/10.24215/16696581e399

\title{
Ensayo General de mis sentimientos
}

\section{General rehearsal of my feelings}

Florencia Cremona,

Feminista, Dra en Comunicación.

Profesora e investigadora de la FPy CS.UNLP

Docente y consultora en género, comunicación y educación.

cremona23@yahoo.com

\section{Resumen}

La vida para mí siempre fue la calle, o la posibilidad de la calle y la casa fue claustrofobia. Ahora mis días son abrumadores, la virtualidad es invasiva. ¿Esto es lo único que podemos hacer?, ¿encerrarnos para escondernos de la muerte que solo parece llegar por un virus corona? Cuidarse podría ser también pensar nuevos modos de asociación. ¿Qué sería repensar el capitalismo? ¿Cómo se puede repensar una máquina con funciones tan falladas y resilientes?

Palabras clave: virtualidad; salud; presente continuo

Key words: virtuality; health; present continuous 
Escribo rápido, de un tirón y con fuerza natural. No reflexiono demasiado. Cada unx lee lo que quiere y entiende lo que siente. Espero no avergonzarme en el futuro. Ok, no se puede evaluar el pasado con las herramientas del presente. Nuestro, presente continuado. Mayo 242020.

Escribo para contarles que la cuarentena me cae mal, muy mal. Experimenté casi todas las emociones posibles menos dos: la romantización del encierro y la consigna de aprovechar el tiempo.

La vida para mí siempre fue la calle, o la posibilidad de la calle y la casa fue claustrofobia. El lujo del hogar siempre me dio mucha vergüenza. No tiene nada que ver con un desprecio "bohemio educada" respecto de los objetos. Es prediscursivo, se lo que vale tener cada cosa y sé que de casi de todo se puede prescindir.

La calle de flâneuse, la calle con azar, la calle para encontrarme conmigo en medio de los ajenos. La calle que me hace inmortal. Inmortal es un término inapropiado hoy día.

Casa está bien para un rato. A veces es un lugar seguro. Tiene fantasmas de esos que te salen de la mente y te atrapan en el pasillo cuando lo cruzas con los pies descalzos. Casa tiene un árbol, comida y abrigo y algún antídoto para cada emoción: duraznos, un Malbec, un libro de magia, chocolates escondidos, secretos míos y así.

Casa me insume un tiempo tremendo, ese que pude tercerizar pagando a otra mujer, no porque sea una privilegiada sino como parte de la inversión necesaria para poder trabajar.

No se puede todo y además tener el vientre plano y la cara sin arrugas y el pelo sin canas. No me interesa igual. Siempre me dijeron terrible, desde muy chiquita, no había nada más peligroso que ser libre pensadora. Con el tiempo, la vida y los libros, me di cuenta que nada está libre para ser pensado. Solo pequeños movimientos de poesía. No se esperaba que sobreviviéramos.

Que olor tendría Corea o París. No quiero pensar en que olor tiene el barrio, porque lo conozco, vivo aquí. Me gusta imaginar lo hay del otro lado del muro.

Limpio, trabajo, limpio, pienso en que me gustaría tener una cocina como la de Juliana López May con una enorme mesada y también con una ventana hacia algún jardín. La mía es un despelote de ollas, me doy cuenta del deterioro y del estado de las cosas. Voy a arreglar. Claro que remodelar o redecorar implicaría clausurarme un tiempo, invadirme de gente que me 
arregle. Entonces no es una decisión segura. Porque si hay normalidad en el futuro, no vamos a comer tanto en casa y no voy a necesitar esas mesadas.

Voy a perfumarme toda, usaré un body negro. Saldremos con amigxs a un bar que será muy diferente a casa. Veré gente querida. Aprendí que el amor tiene opacidades y picos, pero hace que salgamos de los confines de la piel. Esos confines que ahora hay que cerrar para que no entre un virus.

Ahora mis días son abrumadores, la virtualidad es invasiva. Claro que permite cierta fantasía de continuidad como la de los violinistas en la proa del Titanic haciendo lo que tenían que hacer. No estamos en el Titanic.

¿Esto es lo único que podemos hacer?, ¿encerrarnos para escondernos de la muerte que solo parece llegar por un virus corona? Cuidarse podría ser también pensar nuevos modos de asociación. ¿Qué sería repensar el capitalismo? ¿Cómo se puede repensar una máquina con funciones tan falladas y resilientes? Podríamos ser conscientes de que somos de la tierra, de que ella nos contiene.

Doy clases, leo, me concentro poco. Participo en debates anónimos en las redes sociales, me intoxiqué de todo tipo de teorías conspirativas y descubrí que la impotencia frente a una situación límite nos hace creer y crear casi cualquier cosa. Descubrí a David Icke. Está en YouTube y tiene un club de fans argentinos.

Internamente no creo en el virus, no tengo miedo real, me parece que es una enfermedad más. Y que alguien ordenó contar el número de muertos y darles más importancia que a los muertos en la franja de Gaza, a los muertos en las mazmorras del siglo XXI o a los muertos de soledad.

Igual no ando diciendo esto, pretendo ser políticamente correcta. No salgo o salgo lo justo, me pongo tapaboca, uso alcohol en gel.

La corona no ataca, como nada, a todos por igual. El poder real jamás entró en cuarentena y aunque todos podamos morir, los muertos tienen una señal en la frente, una señal que viene de antes. Es un virus mortal pero que se puede evitar lavándose las manos. Todo es muy extraño. Algunos dicen que la maquinaria capitalista paró. No creo. Más bien pienso todo lo contrario. 
Durante la primera fase de la cuarentena europea, cuando todavía no era obligatoria aquí en nuestra pampa llana, me incomodaba bastante toda esta idea de que la tierra necesitara limpiarse y de que los ríos y mares estaban mejor sin barcos ni aviones Entendamos esto: humanos con tecnología creada por humanos filmando lo bien que se ve el mundo sin nosotros. Absurdo. Vi y escuché trescientas veces que el canal de Venecia estaba mejor sin los gondoleros.

No pude evitar pensar qué sería de Venecia sin las góndolas, el Bellini o la Piazza San Marcos filmada para una publicidad suntuosa.

También consumí un poco del guión de La Vita e Bella modo tv en vivo desde los balcones de Italia: cantan, se saludan, brindan. En Miami David Guetta tocó desde una torre y la multitud bailaba, preservada de la pandemia. Lo humano apuesta a la continuidad. Y a la emoción.

¿Porque había que parar?

Hablo demasiado de Europa, es que estamos haciendo lo mismo que en Europa y que en todo el mundo, tal como nos muestra la televisión y los portales de noticias. Paramos.

Pienso en Europa. En Ixs muertxs de Bérgamo. No tengo imagen para China en cambio. No tengo familiaridad con China.

Es todo parecido, lo que nos pasa es lo que le pasa a todo el mundo, aunque debo confesar, muy a mi pesar y solo entre nosotras, que la expresión "actividades esenciales" me suena a los básicos de maquillaje esencial o los must have de las colecciones de ropa. El pantalón negro, la camisa blanca, esos comodines para toda ocasión.

No soy esencial

Entonces.

Estoy discontinuada.

Cambio

de

tema.

En la cuarenta comencé a leer reseñas de perfumes, descubrí uno q se llama Mojave Ghost y promete olor a verano. 
No me puedo concentrar y me angustia la idea de perder el tiempo y como decía antes, mucho peor me resulta la idea de aprovecharlo. Mi origen sociocultural no me permite no hacer nada. Estoy en una situación social prestada. Soy una migrante devenida en influencer. Es vital sentir así, todo está guardado en el ADN.

Pienso en Jesús que tantas gratificaciones emocionales me trajo. Tengo una fe tremenda en Cristo, Cristo de la Caridad. Y también en ciertos íconos culturales que me hicieron de santos, como Evita, que no me falló jamás en nada de lo que le pedí y eso que soy de pedir fuerte cuando pido.

La domesticidad del encierro recreó nociones anticuadas y vigentes de familias y de roles a cumplir dentro de ella, confinó también la actividad sexual y erótica, la ofrenda de cuidados y la noción recursos compartidos por el vínculo. Lxs otros que no viven con nosotrxs son el peligro potencial. La noción de economía familiar se anudó naturalmente a una interdependencia afectiva y emocional. Creencias retrógradas se activaron con la lavandina. familia, heterosexualidad, ingreso por familia, vida eterna.

¿Porque no se decretó el aborto como necesidad y urgencia?

No se pueden usar las camas para abortar, hay que esperar a los futuros muertos

¿Podría llegar a ser verdad esto tan de la autoayuda que dice que el pensamiento plasma realidad? Cuantas veces fantaseamos con apocalipsis, cuantas alacenas Ilenaron nuestros padres por si faltara comida. ¿Cuántas camas se preparan para que lleguen los enfermos? ¿Cuánto dinero hemos ahorrado para los tiempos de escasez?

¿Podríamos acaso ofrecer tutoriales por Instagram con recetas para elevar las defensas? Pienso en remedios caseros que ofrezcan una alternativa complementaria al lavado de manos. Claro que hay que tener en cuenta el tema de la conectividad, accesibilidad, manejo de lenguaje tech. ¿Se entiende a lo que voy? Me refiero a ampliar la noción de salud de la OMS y complementarla para afrontar la continuidad del encierro.

Desde el punto de vista espiritual se supone que venimos a perfeccionar el alma y que elevándonos por encima de las circunstancias podremos encontrar las leyes que rigen el universo trascendiendo las pequeñas miserias humanas. Esa sería una opción. En cambio, una perspectiva hedonista y sociológica diría que la sociedad es lo que hizo su cultura de modo que 
todo eso de parar y observar a la naturaleza recuperarse sería un discurso apócrifo. $Y$ desde mi perspectiva detestable. Me repito.

Detesto muchas cosas, eso baja mi popularidad. Mejor me vuelvo fascinante y sonriente, al fin y al cabo, solo soy una mujer sin espónsor y ya por empezar la curva de la vida, mejor me quedo en el molde, porque cuando todo vuelva a la normalidad quisiera ir de vacaciones a Corea.

Parasite.

¿Qué es la naturaleza, un documental del Nacional Geographic? Somos la naturaleza, de modo que somos la tierra y todas somos mortales. Pensar en esto sí es lindo, hace que algunas diferencias se vuelvan absurdas. Aquí encuentro algo bonito para decir: muchas diferencias se me hicieron absurdas. Digamos que es un efecto positivo de mi pandemia.

¿Que querría ser si no fuese lo que soy?

Veo los vidrios sucios. Cuanta atención y energía ponemos en que todo esté perfecto. Las cosas, el tiempo que invertimos en las cosas. En dulce en una cazuela para no comer desde el tarro. Un mantel con los individuales. Y que se vea bonito. Eternizar el instante, buscar formas amables. Sobrevivir. Porque no se esperaba que sobreviviéramos.

¿Vivo con un perro y cómo llegué a esta situación? Tengo un perro muy grande que suelta pelo por toda la casa Mi hijo tiene 13 años y una enorme corona de pelo rizado. Este año le entregué un libro comprado hace un tiempo, El guardián del Centeno se titula. No sé si lo leyó porque juega bastante a la Play Station.

¿En quién estaba pensando cuándo no pinté esa pared?

Tengo el TEG, una amiga adolescente me recomendó que era mejor el Juego de la Vida, cuando debatíamos en un local de Jumbo Escobar sobre qué juego era mejor para una noche de verano Tenía razón, el TEG atrasa, el azar de comprar propiedades es mucho más efectivo. Tiene más adrenalina. Es una joven muy intuitiva. 
Vi otra vez Forrest Gump y varias películas porque mi compra del pánico fue un televisor Smart UHD y una juguera. Creo que ya comenté lo de la juguera.

Aún no resolví quién es mi actriz contemporánea favorita. Hubiese dicho que Portman, aunque me resulta demasiado distante, Scarlett es increíble pero definitivamente Kate Winslet me encanta mucho más. Recomiendo Revolutionary Road.

De las actrices argentinas me conmovió tanto Graciela Borges en la Ciénaga, qué bien representaba las cadenas y los miedos que nos habitan y nos dejan literal postradas en la reposera. La ciénaga propia. Valeria Bertuccelli me gusta bastante, aunque mi marido dice que siempre hace de sí misma. Lástima que se peleó con un padrino de la actuación como Ricardo Darín y dejó de ser convocada. Tal vez no sea tan buena actriz.

Ya no me queda Miss Dior. Creo que lo dije también.

Mi mejor amigo me habla bastante de The Crown, una serie que vi varias veces. ¿Cómo sería nacer con linaje? En la universidad me enseñaron que las clases dominantes nos hicieron creer a nosotros, los sectores populares, que no teníamos historia. Lo sé, también tenemos linaje, pero en esta oportunidad estoy hablando de otra cosa.

Victoria Ocampo, pienso en ella. Sabía demasiado de organza y de manteles de lino, desde siempre una mujer fascinante. También admiro a Madonna y a Maradona, aunque eso es casi inevitable para alguien de mi generación. En general estamos entrenadas para admirar a quien alcanza el éxito rompiendo el sino del destino. Admiro a personas no conocidas, de hecho, la mayoría de las personas que admiro no se encuentran casi en Google.

Pero quería compartir mis lecturas: Un golpe al Corazón de Amelie Nothomb sencilla y letal. Sumisión es un gran libro también, no recuerdo como se escribe el apellido del autor.

Del encierro una de las actividades que más disfruto es conversar con amabilidad. A todas nos hace sentir seguras. Nos ayuda a dejar de temer la amenaza de ese infierno que Sartre decía que eran los otros. Sartre era un varón, por eso tenía que ganar o competir o demostrarse algo a sí mismo.

Nosotras, al menos este nosotras que me habita que también podría ser imaginario, no queremos crear infiernos, queremos crear espacios tibios y vivir deseando. Ponerle nombre a nuestro destino. Decir quiero y también no quiero. No puedo. 
Cuantas cosas que sé ahora, seré mejor al salir.

Podríamos no salir más, cien años no son nada para la historia de la humanidad. Apenas setenta años que podemos votar las mujeres y todavía no nos es permitido abortar legalmente y en forma segura y digna.

Nunca somos urgentes ni esenciales.

Me gusta que me hayan invitado a escribir, me siento agradecida.

Quiero decir tantas cosas y a la vez tengo un enorme deseo de callar. El silencio ha sido para nosotras un confinamiento performativo, un modo activo de resguardo y progreso, de observación subalterna. De acción poética, de supervivencia. No se esperaba que sobreviviéramos.

Y ahora, el tiempo nos recoloca en el mundo con un futuro inmediato borroso. Un tiempo que nos obliga a ser presente continuado. Inhalo y exhalo acá y ahora. Los planes, las desobediencias, los pesos, lo pequeño, lo mínimo Es todo. Ahora es todo. Es esto, un ensayo general de mis sentimientos, desde los confines de mi piel. 